\title{
混合アルコキシドの水熱処理による 結晶性ムライト微粉体の低温合成
}

(1983 年 9 月 22 日受理)

鈴木松 郎*・平石俊一**・吉村昌弘・宗富重行

\begin{abstract}
$\mathrm{Al}_{2} \mathrm{O}_{3}: \mathrm{SiO}_{2}$ モル比=3:2 の混合アルコキシド溶液を $300^{\circ} \mathrm{C}, 50 \mathrm{MPa}$ で 30 分間水熱処理したのち 水洗し, 再度 $300 \sim 600^{\circ} \mathrm{C}, 10 \sim 100 \mathrm{MPa}$ で水熱処理した。その結果, 压力を $20 \mathrm{MPa}$ 以上とすれば $600^{\circ} \mathrm{C}, 2$ 時間といら低温短時間の反応でムライト $\left(3 \mathrm{Al}_{2} \mathrm{O}_{3} \cdot 2 \mathrm{SiO}_{2}\right)$ 微粉末が生成した。しかし, 600 ${ }^{\circ} \mathrm{C}$ で $30 \mathrm{MPa}$ 以上の 水熱処理を行なった場合は八イドラルサイト $\left(2 \mathrm{Al}_{2} \mathrm{O}_{3} \cdot 2 \mathrm{SiO}_{2} \cdot \mathrm{H}_{2} \mathrm{O}\right), \mathrm{AS}(\mathrm{H})$ II $\left(5 \mathrm{Al}_{2} \mathrm{O}_{3} \cdot 2 \mathrm{SiO}_{2} \bullet n \mathrm{H}_{2} \mathrm{O}\right)$ などの $\mathrm{Al}_{2} \mathrm{O}_{3}-\mathrm{SiO}_{2}$ 系水和物がムライトに優先して生成するため, 均一組 成のムライト粉体は得られず，乙たがって $600^{\circ} \mathrm{C}$ 以上 $30 \mathrm{MPa}$ 以下の水熱条件がムライト生成の好適 条件であることがわかった。 $600^{\circ} \mathrm{C}, 20 \mathrm{MPa} て ゙ 2 〜 168$ 時間水熱処理したところ，2 時間で長さ 100 $\mathrm{nm}$, 幅 $5 \mathrm{~nm}$ の針状の微粒子が生成し，処理時間が長くなるにとるない針状粒子の大きさが增大し 168 時間では長さ $1 \mu \mathrm{m}$ 以上, 幅 $20 \mathrm{~nm}$ の針状粒子となった。また EDS 分析の結果, 168 時間の処 理で生成した針状粒子は $\mathrm{Al}_{2} \mathrm{O}_{3}: \mathrm{SiO}_{2}$ モル比 $=3: 2$ の均一な組成であり, 赤外吸収スペクトルからも ムライトであることが明らかになった。
\end{abstract}

\section{1 緒 言}

$1 \mu$ 以下の超微粉末は表面活性が高く，従来の粉末には見られ ない特性を有することが多く, セラミックス, 触媒, 塗料, 磁性 体, 充填棛など多岐の分野において新しい展開が期待できる新素 材である。このような超微粉体には, 単に微細であることばかり ではなく，高純度であること，粒度分布が狭いこと，あるいは凝 集性を示さないことなとが同時に要求されることが多く, 粒子形 状を制御することが重要である。セラミックスにおいても微構造 を再現性よく，きめ細かに制御し，信頼性のある焼結体を作成す るために超微粉体が要求されるようになっだ。とくに均一な組成 の化合物あるいは固溶体のセラミックスを得るためには，微細な 単位で構成成分を均一に混合しておくことが必要であり，超微粉 体への要請が高まっだ122。

ムライト $\left(3 \mathrm{Al}_{2} \mathrm{O}_{3} \cdot 2 \mathrm{SiO}_{2}\right)$ は $\mathrm{Al}_{2} \mathrm{O}_{3}-\mathrm{SiO}_{2}$ 系の常圧で安定な 唯一の化合物であるが純粋なるのは容易には得られないる。その 一因はムライトが分解溶融化合物であり，また準安定状態も含め て幅広い、固溶領域を有するためといわれている4)。したがって純 粋なムライトを得るためには，アルカリなどの不純物を除くとと

東京工業大学工業材料研究所, 227 横浜市緑区長津田町

**大日本インキ化学工業株式会社, 103 東京都中央区日本橋

1) K.S. Mazdiyasni, Ceram. Int., 8, 42(1982).

2）尾崎義治, 工業材料, 29, 85(1981).

3) R.F.Davis, J.A. Pask, "High Temperature Oxide, Part N", A. M. Alper ed., Academic Press, New York, N. Y. (1971) p. 37.

4) I. A. Aksay, J.A.Pask, J. Am. Ceram. Soc., 58, 507 (1975).
もに，均一な組成にするための努力が必要である。これまでにも 種々の方法で作成した微粉体を用いてムライトを合成する研究が 行なわれたが5) 8)，近年では金属アルコキシドを加水分解または 加熱分解して得た酸化物微粉末を用いる方法 (アルコキシド法) が Mazdiyasni，Brown9) らにより研究され10) 12), 耐熱高強度 ムライト成形体 ${ }^{918}$ ），透光性薄膜 ${ }^{11) 12}$ などが得られている。この アルコキシド法は溶液状態で各成分を均一混合することができ, しかも高純度の微粉体が得られるなどの特長を有する1)2。

一方, 高温高压の水を反応媒体として用いるセラミックス原料 粉体の水熱合成法は常圧下の固相反応による合成法と比較して低 温で反応が進行し, 高純度の結晶性粉末が得られるなどの利点を

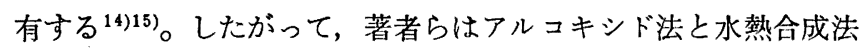

5) R. Roy, J. Am. Ceram. Soc., 39, 145(1951).

6）大谷杉郎, 小島 昭, 工化, 67, 1509(1964).

7) J.D. Crofts, W. W. Marshall, Trans. J. Brit. Ceram. Soc., 66, 121(1967).

8) B. B. Ghate, D. P. H. Hasselman, R. M. Spriggs, Am. Ceram. Soc. Bull., 52, 670(1973).

9) K. S. Mazdiyasni, L. M. Brown, J. Am. Ceram. Soc., 55, 548(1972).

10) B. L. Metcalfe, J. H. Sant, Trans. J. Brit. Ceram. Soc., 74, 193(1975).

11) B.E. Yoldas, Am. Ceram. Soc. Bull., 54, 286(1975).

12）尾崎義治, 秀島正明, 児島洋子, 篠田政昭, 案業協会年会 講演予稿集, p. 124(1980).

13) P.C. Dokko, J. A. Pask, K. S. Mazdiyasni, J. Am. Ceram. Soc., 60, 150(1977).

14）中村辉太郎, 中田一郎編, 宗宮重行, “試料の作成と加工”, 共立出版（1981） p. 181 . 
の利点を組み合わせる目的で $\mathrm{Al}_{2} \mathrm{O}_{3}: \mathrm{SiO}_{2}=3: 2$ (モル比) の混 合アルコキシド溶液を直接水熱処理する方法を検討した ${ }^{16)}$ 。その 結果 $300 \sim 400^{\circ} \mathrm{C}, 10 \sim 100 \mathrm{MPa}, 2$ 時間の水熱処理により $\mathrm{Al}$ 成 分と Si 成分が均一に分布した擬ベーマイト類似相の微結晶が得 られ，これを空気中で $1300^{\circ} \mathrm{C}$ 以上に焼成すれば高純度のムライ 卜単一相からなる微粉体が得られることを明らかにした ${ }^{17) 。 ~}$

しかしこのよらな水熱処理物の焼成によってではなく, 水熱処 理だけで直接ムライトを合成できれば工程も短くエネルギー消費 量も小さくなるので，この方法を開発することが望まれる。しか しながらアルコキシド溶液を $500^{\circ} \mathrm{C}$ 以上で水熱処理して $\mathrm{Al}_{2} \mathrm{O}_{3}$ $\mathrm{SiO}_{2}$ 間の反応を進行させようとした場合，アルコキシド溶液に 含まれる有機物が擬ベーマイトト類似相を安定化し，その後の反応

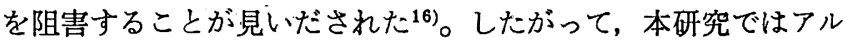
コキシドの水熱処理により，まず $\mathrm{Al}$ 成分と $\mathrm{Si}$ 成分が均一に分布 した擬ベーマイト類似相を得たのち，水洗して有機物を除去し再 度水熱処理することによって結晶性ムライト微粉体を合成する方 法を検討した。

\section{2 実験}

\section{1 原料 調製}

かきまぜ機付き $500 \mathrm{~m} l$ 四つロフラスコにアルミニウム=イソプ ロポキシド，川研ファインケミカル(株)製：分子式 $\left(i-\mathrm{C}_{3} \mathrm{H}_{7} \mathrm{O}\right)_{3}$ $\mathrm{Al}$, (略記号 AIPD, 分子量 204.2 , 融点 約 $131^{\circ} \mathrm{C}$, 比重 1.035 , $\mathrm{Al}$ 含有量 $13.2 \pm 0.2 \%$, 純分 $99 \%$ 以上） $88.2 \mathrm{~g}$ とテトラェトキ シケイ素（オルトケイ酸テトラエチル 28 , 比重 $0.93 \sim 0.94$, 有 効 $\mathrm{SiO}_{2}$ 分 $28.8 \%$ ，残存塩酸分 $0.01 \%$ 以下） $30.0 \mathrm{~g}$ とを科取した (この場合 $\mathrm{Al}_{2} \mathrm{O}_{3}: \mathrm{SiO}_{2}$ モル比=3:2 となる)。ここにべンゼ ン $240 \mathrm{ml}$ を加兄, 乾燥窒素気流中, 還流下 $\left(78 \sim 80^{\circ} \mathrm{C}\right)$ で 5 時 間かきまぜ溶解し，混合アルコキシドのベンゼン溶液を得て水熱 処理用の出発試料とした。

\section{2 水熱処理 I}

試料溶液を入れた内径 $8 \mathrm{~mm}$, 長さ $60 \mathrm{~mm}$ の開ロカプセルを Tuttle, Roy 式圧力容器に蒸留水とともに入れ，日機装(株)製水 熱合成装置 (TMP-MI 型) を用いて $300^{\circ} \mathrm{C}, 50 \mathrm{MPa}$ ま昇温加 圧し 30 分間保持した。温度は圧力容器外壁に取り付けたプラチ ネル熱電対により測定し，昇温速度は $2.5^{\circ} \mathrm{C} / \mathrm{min}$ とした。

\section{3 水 洗}

$300^{\circ} \mathrm{C}, 50 \mathrm{MPa}$ に保持したのち, 圧力調節弁特よび水压ポンプ を用いて 0 50 MPa に減圧-加圧操作を 5 回くり返して内容物を 水洗し, ベンゼン, アルコール類などの有機溶媒を除去した。な お，有機溶媒は 3 回以上の水洗操作で除去され，4〜 5 回目の洗

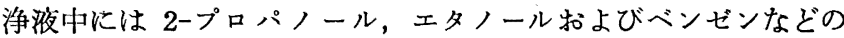
有機溶媒はガスクロマトグラフィーによってもまったく検出され なかった。

\section{4 水熱处理 II}

水洗後, 圧力を大気圧とし $2.5^{\circ} \mathrm{C} / \mathrm{min}$ の昇温速度で $300 \sim 600$ ${ }^{\circ} \mathrm{C}$ の所定の温度まで加熱した。所定温度に到達後, 10 100 MPa

15）宗宮重行, 吉村昌弘，機能材料，13，（5)，56(1983).

16）宗宮重行，吉村昌弘，鈴木松郎，平石俊一，粉体および粉 末治金，31，8 号掲載予定（1984）。

17）鈴木松郎，平石俊一，吉村昌弘，宗宮重行，筧協，92，6 号掲載宁定 (1984).
の所定の圧力まで加圧し，ふたたび水熱処理した。水熱処理時間 は 2〜168 時間とした。

水熱処理終了後, 圧力容器を水につけて急冷し, 試料容器から 水熱処理生成物を約 $10 \mathrm{~m} l$ の蒸留水でパイレックスビーカーに流 出し，そのまま $120^{\circ} \mathrm{C}, 24$ 時間，空気中で乾燥した。

\section{$2.5 \mathrm{X}$ 線粉末回折法}

乾燥試料をめのう乳鉢でェタノールを用いて湿式粉砕し，理学 電機 (株) 製ロータフレックス RU-200 型X線粉末回折装置を用 いて $\mathrm{Cu} K_{\alpha}$ 線により生成相を同定した。

\section{6 電子顕微鏡（TEM, SEM）観察およびエネルギー分散分} 析

粉䂗した試料粉末を超音波により水中に分散後、コロジオン膜 をはった銅メッシュですくい取り，日本電子(株)製 EDS TEM SCAN-200 CDX 透過型分析顕微鏡を用いて粉末形状の観察およ びェネルギー分散 (EDS) 分析を行なった。また，粉末を超音波 によりェタノール中に分散した液をアルミニウムプレート上に滴 下し，風乾したのち，金蒸着を行ない，日本電子(株) 製 JSM-T 200 型走査型電子顕微鏡によっても粉末の観察を行なった。

\section{7 赤外吸収スペクトル}

粉䂗した試料粉末を $\mathrm{KBr}$ 中に分散し，錠剤を作成して日本分 光(株)製 A-202 型赤外分光光度計を用いて, 赤外吸収スペクト ルを測定した。

\section{3 結果および考察}

$\mathrm{Al}_{2} \mathrm{O}_{3}: \mathrm{SiO}_{2}$ モル比=3:2 の混合アルコキシドのベンゼン溶 液を直接, 温度 $300,400,500,600^{\circ} \mathrm{C}$, 圧力 $10,50,100 \mathrm{MPa}$ で 2 時間水熱処理した生成物の X線回折法による同定結果を表 1 に示した。また表 2 には同じ混合アルコキシド溶液を $300^{\circ} \mathrm{C} ， 50$ $\mathrm{MPa}$ で 30 分間水熱処理したのち，水洗し，300 $600^{\circ} \mathrm{C}$, 圧力 10〜100 MPa で 2 時間水熱処理した生成物の同定結果を示した。

アルコキシドを直接水熱処理した場合（表 1）は擬べーマイト 類似相の生成する温度一圧力の笧囲が広く，そのため $\mathrm{Al}_{2} \mathrm{O}_{3}-\mathrm{SiO}_{2}$ 系の結晶性水和物であるハイドラルサイト $\left(2 \mathrm{Al}_{2} \mathrm{O}_{3} \cdot 2 \mathrm{SiO}_{2}\right.$.

Table 1 Products prepared by the hydrothermal treatment (for $2 \mathrm{~h}$ ) of mixed alkoxide $\left(\mathrm{Al}_{2} \mathrm{O}_{3}: \mathrm{SiO}_{2}\right.$ $=3: 2$, mole ratio) — treated directly-

\begin{tabular}{cccc} 
Temperature & \multicolumn{3}{c}{ Pressure(MPa) } \\
\cline { 2 - 4 }$\left({ }^{\circ} \mathrm{C}\right)$ & 10 & 50 & 100 \\
\hline 300 & $\mathrm{~B}$ & $\mathrm{~B}$ & $\mathrm{~B}$ \\
400 & $\mathrm{~B}$ & $\mathrm{~B}$ & $\mathrm{~B}$ \\
500 & $\mathrm{~B}^{a)}$ & $\mathrm{B}^{a)}$ & $\mathrm{B}+\mathrm{H}+\mathrm{A}^{a)}$ \\
600 & $\mathrm{Am}^{a)}$ & $\mathrm{S}^{a}$ & $\left.\mathrm{~A}+\mathrm{H}+\mathrm{S}+\mathrm{M}^{a}\right)$
\end{tabular}

a) With hydrocarbon

B : Pseudoboehmite $(\boldsymbol{\gamma}-\mathrm{AlOOH})-$ like phase

$\mathrm{H}$ : Hydralsite $\left(2 \mathrm{Al}_{2} \mathrm{O}_{3} \cdot 2 \mathrm{SiO}_{2} \cdot \mathrm{H}_{2} \mathrm{O}\right.$; after Roy and Osborn (1954))

A : AS(H)-II (close to $\mathrm{Al}_{2} \mathrm{SiO}_{5}$; after Aramaki and Roy (1963))

$\mathrm{M}:$ Mullite $\left(3 \mathrm{Al}_{2} \mathrm{O}_{3} \cdot 2 \mathrm{SiO}_{2}-2 \mathrm{Al}_{2} \mathrm{O}_{3} \cdot \mathrm{SiO}_{2}\right)$

Am : Amorphous phase, $\mathrm{S}: \mathrm{Al}-\mathrm{Si}$ Spinel

18) R. Roy, E. F. Osborn, Am. Mineral., 39, 853(1954).

19) S. Aramaki, R. Roy, ibid., 48, 1322(1963). 
Table 2 Products prepared by the hydrothermal treatment (for $2 \mathrm{~h}$ ) of mixed alkoxide $\left(\mathrm{Al}_{2} \mathrm{O}_{3}: \mathrm{SiO}_{2}\right.$ $=3: 2$, mole ratio)—Treated after washing at $300^{\circ} \mathrm{C}$

\begin{tabular}{cccc} 
Temperature & \multicolumn{3}{c}{ Pressure(MPa) } \\
\cline { 2 - 4 }$\left({ }^{\circ} \mathrm{C}\right)$ & 10 & 50 & 100 \\
\hline 300 & $\mathrm{~B}$ & $\mathrm{~B}$ & $\mathrm{~B}$ \\
400 & $\mathrm{~B}$ & $\mathrm{~B}$ & $\mathrm{~B}$ \\
500 & $\mathrm{~B}$ & $\mathrm{~B}+\mathrm{H}$ & $\mathrm{B}+\mathrm{H}+\mathrm{A}$ \\
600 & $\mathrm{~S}$ & $\mathrm{~A}+\mathrm{H}+\mathrm{S}+\mathrm{M}$ & $\mathrm{A}+\mathrm{H}+\mathrm{S}+\mathrm{M}$
\end{tabular}

B : Pseudoboehmite ( $\gamma$-AlOOH)-like phase

$\mathrm{H}$ : Hydralsite $\left(2 \mathrm{Al}_{2} \mathrm{O}_{3} \cdot 2 \mathrm{SiO}_{2} \cdot \mathrm{H}_{2} \mathrm{O}\right.$; after Roy and Osborn (1954))

A : AS. $(\mathrm{H})-\mathrm{II}$ (close to $\mathrm{Al}_{2} \mathrm{SiO}_{5}$; after Aramaki and Roy (1963))

$\mathrm{M}$ : Mullite $\left(3 \mathrm{Al}_{2} \mathrm{O}_{3} \cdot 2 \mathrm{SiO}_{2}-2 \mathrm{Al}_{2} \mathrm{O}_{3} \cdot \mathrm{SiO}_{2}\right)$

Am : Amorphous phase, $\mathrm{S}: \mathrm{Al}-\mathrm{Si}$ Spinel

$\left.\mathrm{H}_{2} \mathrm{O}\right)^{17) 18)}$ 扎よび $\mathrm{AS}(\mathrm{H})-\mathrm{II}\left(5 \mathrm{Al}_{2} \mathrm{O}_{3} \cdot 2 \mathrm{SiO}_{2} \cdot n \mathrm{H}_{2} \mathrm{O}\right)^{17) 10)}$ が生 成するためには $100 \mathrm{MPa}\left(500 \sim 600^{\circ} \mathrm{C}\right)$ の圧力を必要とした。

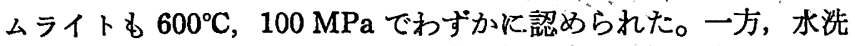
して有機物を除去したのち, 水熱処理した場合は, ハイドラルサ イトおよひ AS (H)-IIの生成圧力は $50 \mathrm{MPa}$ まで低下した。同 様にムライトの生成圧も $50 \mathrm{MPa}\left(600^{\circ} \mathrm{C}\right)$ に低下した。

既報 ${ }^{16)}$ に報告したように，アルコキシドを直接水熱処理した場 合には系中に存在するベンゼンあるいはアルコール類などの有機 溶媒が生成結晶粒へ吸着されたり，氷分圧の低下を引き起こした りするため, 擬ベーマイト類似相の微結晶が安定化され, ハイド ラルサイト, AS (H)-I あるいはムライトの生成が抑制される。 我熱条件下でムライト粉末を直接調製することを目的とする本研 究では, 反応の阻害要因となる有機物を水洗除去したのち水熱処 理を進めた。

\section{1 水熱処理温度の影響}

$10 \mathrm{MPa}$ の圧力下で水熱処理した場合, 図1 亿X 線回折困形を 示したように，300〜 $500^{\circ} \mathrm{C}$ では低結晶性の擬ベーマイト類似相 が生成し， $600^{\circ} \mathrm{C}$ で擬べーマイト類似相が消隇して $\mathrm{Al}-\mathrm{Si}$ スピネ

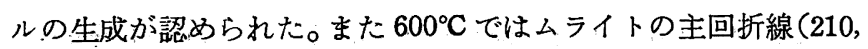
120) に相当する角度 ( $\left(2 \theta=25 \sim 27^{\circ}\right)$ にわずかに幅広い回折線が 見られた。

$50 \mathrm{MPa}$ で水熱処理した場合（図 2), 擬ベーマイト類似相は $500^{\circ} \mathrm{C}$ で分解し始めハイドラルサイトが生成した。600 ペーマイト類似相は消隇し，ハイドラルサイトおよび AS(H)-II が主生成相となり，A1-Si スピネルおよび微量のムライトの生成 も認められた。100 MPa の場合（因 3）も50 MPa の場合とほ ぼ同様の結果となった。

\section{2 水熱処理圧力の影響}

表 2 からかかように, $600^{\circ} \mathrm{C}$ の水熱処理では $10 \mathrm{MPa}$ で Al$\mathrm{Si}$ スピネルが生成し, $50 \sim 100 \mathrm{MPa}$ でハイドラルサイト， AS (H)-II，A1-Si スピネルとともにムライトが生成した。既報で報 告したように，擬ベーマイト類似相を空気中で加熱焼成した場合

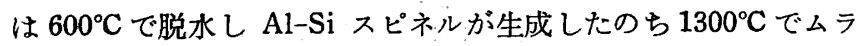

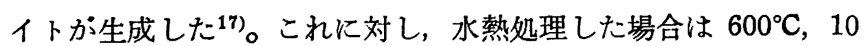
$\mathrm{MPa}$ で Al-Si スピネルが生成し，600年，50〜100 MPa ではわ ずかではあるがムライトが生成した。このように玨力を上昇させ

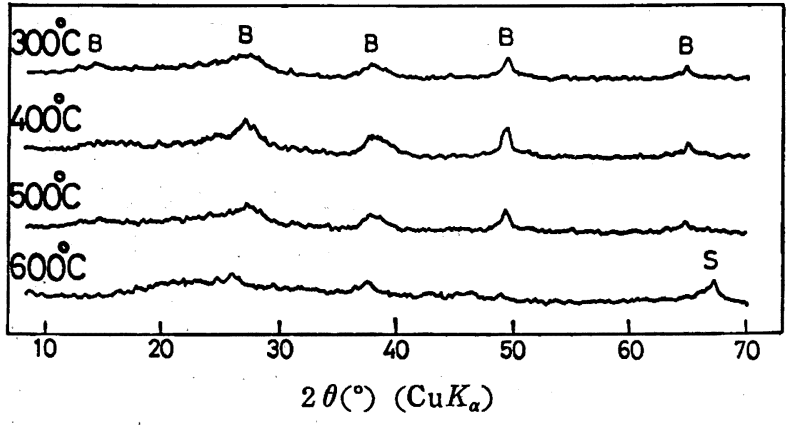

Fig. $1 \mathrm{X}$-ray powder diffraction patterns of products prepared by the hydrothermal treatment of mixed alkoxide $\left(\mathrm{Al}_{2} \mathrm{O}_{3}: \mathrm{SiO}_{2}=3: 2\right.$, mole ratio), at various temperatures under $10 \mathrm{MPa}$ for $2 \mathrm{~h}$

Treated after washing with distilled water at $300^{\circ} \mathrm{C}$. B : Pseudoboehmite-like phase, S : Al-Si Spinel

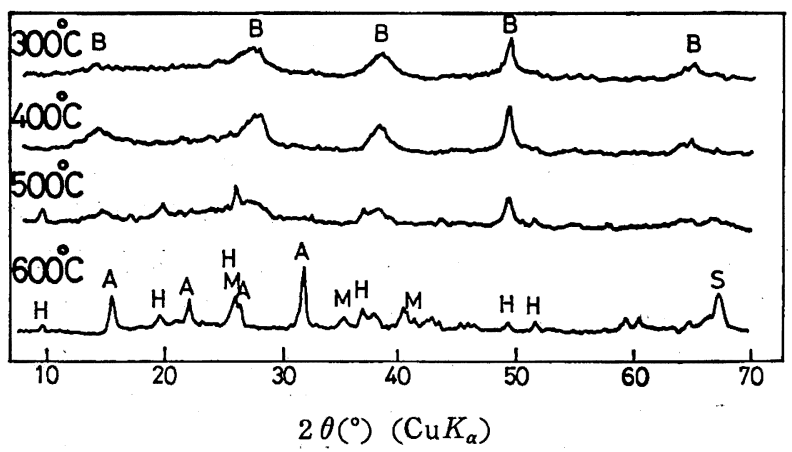

Fig. 2 X-ray powder diffraction patterns of products prepared by the hydrothermal treatment of mixed alkoxide $\left(\mathrm{Al}_{2} \mathrm{O}_{3}: \mathrm{SiO}_{2}=3: 2\right.$, mole ratio), at various temperatures under $50 \mathrm{MPa}$ for $2 \mathrm{~h}$

Treated after washing with distilled water at $300^{\circ} \mathrm{C}$. B : Pseudoboehmite-like phase, $\mathrm{H}$ : Hydralsite, A : AS (H)-II, M : Mullite, S: Al-Si Spinel

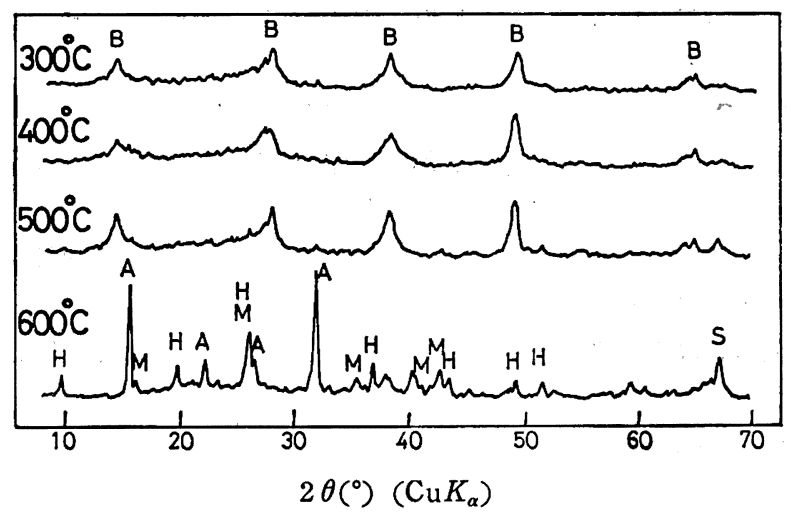

Fig. $3 \mathrm{X}$-ray powder diffraction patterns of products prepared by the hydrothermal treatment of mixed alkoxide $\left(\mathrm{Al}_{2} \mathrm{O}_{3}: \mathrm{SiO}_{2}=3: 2\right.$, mole ratio), at various temperatures under $100 \mathrm{MPa}$ for $2 \mathrm{~h}$

Treated after washing with distilled water at $300^{\circ} \mathrm{C}$. B : Pseudoboehmite-like phase, $\mathrm{H}$ : Hydralsite, A : AS (H)-II, M : Mullite, S : Al-Si Spinel 


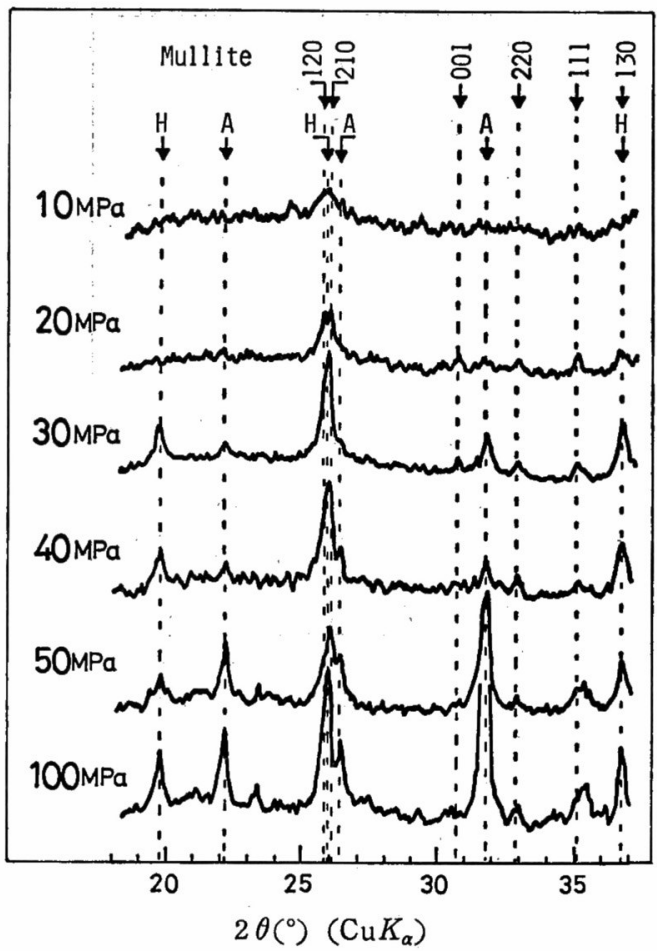

Fig. 4 X-ray diffraction patterns of products prepared by the hydrothermal treatment of mixed alkoxide $\left(\mathrm{Al}_{2} \mathrm{O}_{3}: \mathrm{SiO}_{2}=3: 2\right.$, mole ratio), under various pressures at $600^{\circ} \mathrm{C}$ for $2 \mathrm{~h}$

Treated after washing with distilled water at $300^{\circ} \mathrm{C}$. $\mathrm{H}:$ Hydralsite, A : AS (H)-II

ることにより $\mathrm{Al}_{2} \mathrm{O}_{3}-\mathrm{SiO}_{2}$ 間の反応を促進させムライトを生成さ せ得るが，乙かし同時に， $\mathrm{H}_{2} \mathrm{O}$ との反応も促進され， $50 \mathrm{MPa}$ 以 上の水熱処理では八イドラルサイト, AS ( H)-IIなどの水和物の 生成が優先するものと考学られる。したがってムライトを效率的 に生成させるためには, $600^{\circ} \mathrm{C} て ゙ ~ 10 \mathrm{MPa}$ 以上 $50 \mathrm{MPa}$ 以下の圧 力下で水熱処理することが好ましいものと考兄られる。

そこで温度を $600^{\circ} \mathrm{C}$ として圧力を $10 ， 20 ， 30 ， 40 ， 50$ お。 び $100 \mathrm{MPa}$ と変えて 2 時間水熱処理した。生成物の X 線回折図形 (図 4) からわかるようにムライトは 20〜30 MPa でもっとも多 く生成し，それ以上圧力を增しても生成量は増大しなかった。一 方, 八イドラルサイトおよび AS (H)し; しかむ压力の上昇にともない生成量が増大した。したがって ムライト生成のための最適条件は $600^{\circ} \mathrm{C}, 20 \mathrm{MPa}$ と判断できる。

Roy, Osborn ${ }^{18)}$ はカオリナイト，共沈ゲルなどを出発物質と して用いた水熱平衡研究に打いて， $485^{\circ} \mathrm{C}$ 以上， $5000 \sim 8000 \mathrm{psi}$ （35 55 MPa）3〜30 日でムライトの生成を認めている。また， De Vijnck ${ }^{20)}$ は $\mathrm{Al}_{2} \mathrm{O}_{3}: \mathrm{SiO}_{2}$ モル 比=3:2 の共沈ゲルを $600^{\circ} \mathrm{C}$, $400 \mathrm{~kg} / \mathrm{cm}^{2}$ (39. $2 \mathrm{MPa}$ ) で 7 日間水熱処理してムライトを得て いる。これに対し, 本研究では $600^{\circ} \mathrm{C}, 20 \mathrm{MPa}$ の条件でわずか 2 時間の水熱処理によりすでにムライトが生成していることが認 められた。

な和出発試料混合アルコキシド中に含まれる不純物はスパーク マス分析の結果, K $64 \mathrm{ppm}, \mathrm{Zr} 61 \mathrm{ppm}, \mathrm{Na} 15 \mathrm{ppm}, \mathrm{Cl} 14 \mathrm{ppm}$, $\mathrm{B} 12 \mathrm{ppm}$ (いずれも $3 \mathrm{Al}_{2} \mathrm{O}_{3} \cdot 2 \mathrm{SiO}_{2}$ 固形分に対する重量比)で 20) Y.De Vijnck, Silicates Ind., 41, 451(1976).

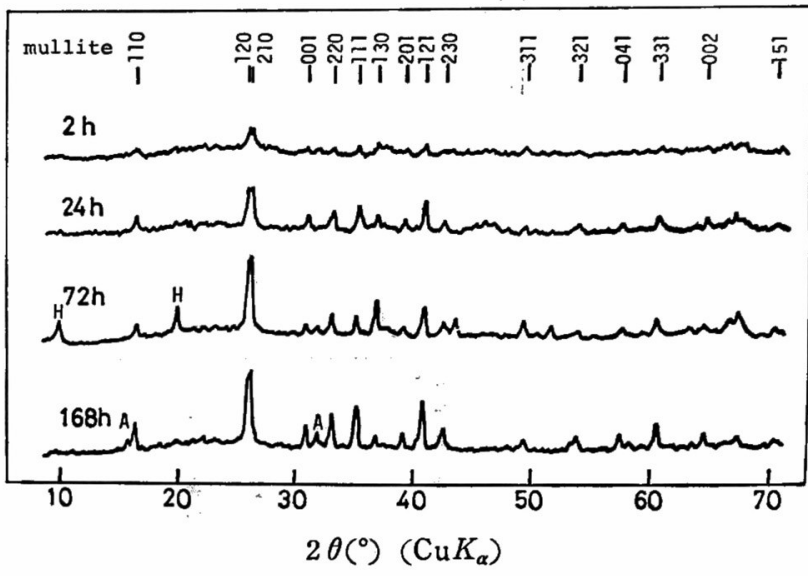

Fig. $5 \mathrm{X}$-ray powder diffraction patterns of products prepared by the hydrothermal treatment of mixed alkoxide $\left(\mathrm{Al}_{2} \mathrm{O}_{3}: \mathrm{SiO}_{2}=3: 2\right.$, mole ratio), at $600^{\circ} \mathrm{C}$ under $20 \mathrm{MPa}$ for various hours

Treated after washing with distilled water at $300^{\circ} \mathrm{C}$. $\mathrm{H}:$ Hydralsite, A : AS (H)-II

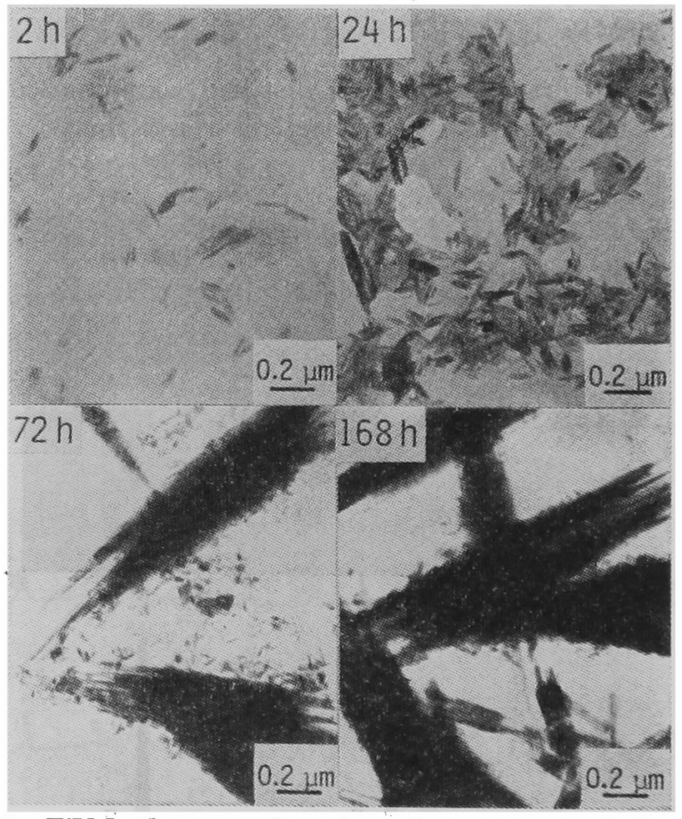

Fig. 6 TEM photographs of products prepared by the hydrothermal treatment of mixed alkoxide $\left(\mathrm{Al}_{2} \mathrm{O}_{3}\right.$ $: \mathrm{SiO}_{2}=3: 2$, mole ratio), at $600^{\circ} \mathrm{C}$ under $20 \mathrm{MPa}$ for various hours

Treated after washing with distilled water at $300^{\circ} \mathrm{C}$.

あった。一方, $600^{\circ} \mathrm{C}, 20 \mathrm{MPa} 2$ 時間の水鶖处理生成物では $\mathrm{Ca}$ $92 \mathrm{ppm}, \mathrm{Fe} 60 \mathrm{ppm}, \mathrm{Ga} 50 \mathrm{ppm}, \mathrm{Na} 44 \mathrm{ppm}, \mathrm{Cl} 40 \mathrm{ppm}, \mathrm{K} 35$ $\mathrm{ppm}, \mathrm{Cu} 40 \mathrm{ppm}, \mathrm{Zn} 20 \mathrm{ppm}$ 以下であり, $100 \mathrm{ppm}$ 以上含ま れる不純物はなく, 出発試料と同程度の純度がほぼたもたれた。 したがって, 本研究の水熱処理に执いては不純物による影響は少 なかったものと考觉られる。

\section{3 水熱処理時間の影響}

$600^{\circ} \mathrm{C}, 20 \mathrm{MPa}$ で 2 168 時間の水熱処理を行なった。これら の生成物のX線回折図形（図 5 ) からわかるように, 水熱処理時 間が長くなるとともにムライトの生成量が增大した。しかし，72 


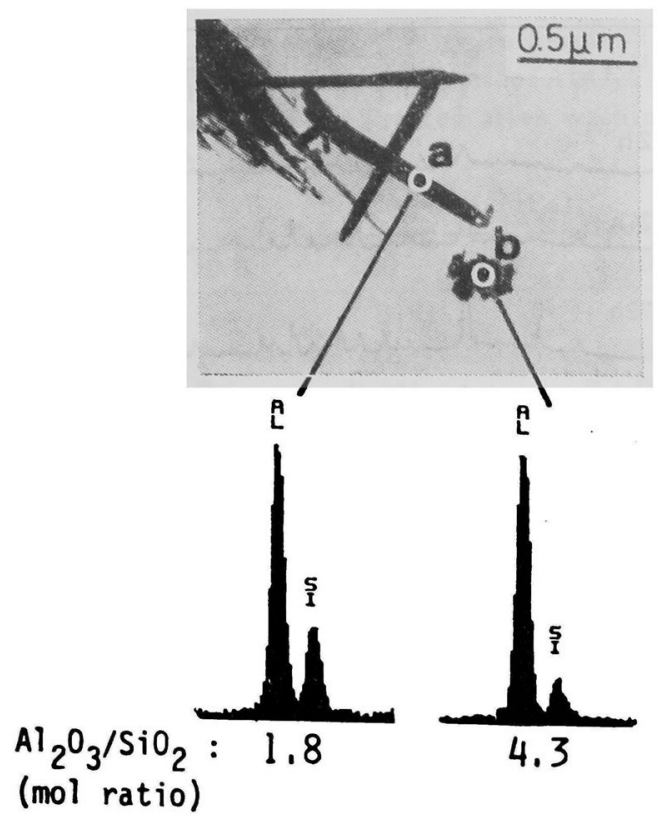

Fig. 7 TEM photograph of the product prepared by the hydrothermal treatment of mixed alkoxide $\left(\mathrm{Al}_{2} \mathrm{O}_{3}: \mathrm{SiO}_{2}=3: 2\right.$, mole ratio), at $600^{\circ} \mathrm{C}$ under $20 \mathrm{MPa}$ for $24 \mathrm{~h}$

Treated after washing with distilled water at $300^{\circ} \mathrm{C}$. With EDS analysis of the particle a and the particle b.

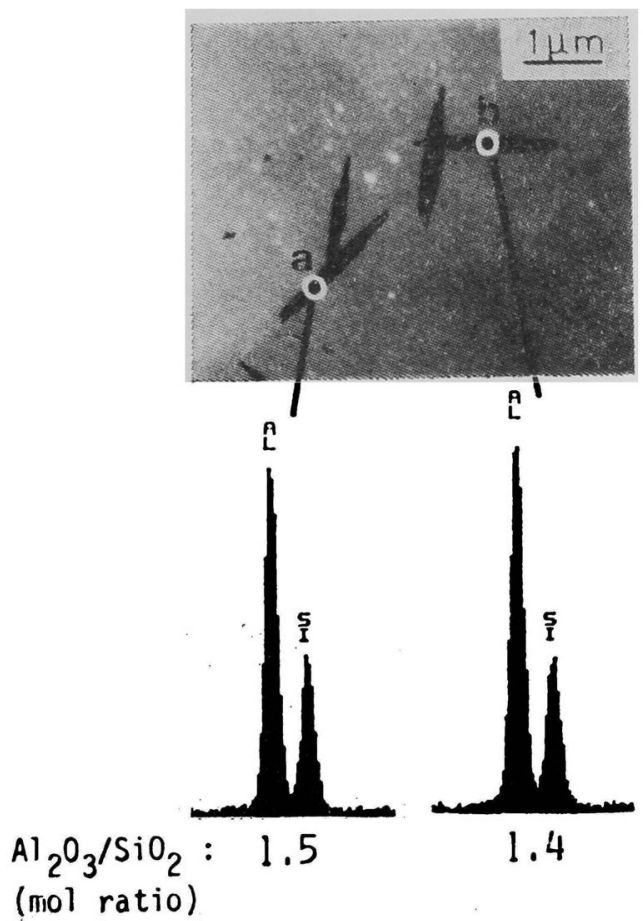

Fig. 8 TEM photograph of the product prepared by the hydrothermal treatment of mixed alkoxide $\left(\mathrm{Al}_{2} \mathrm{O}_{3}: \mathrm{SiO}_{2}=3: 2\right.$, mole ratio), at $600^{\circ} \mathrm{C}$ under $20 \mathrm{MPa}$ for $168 \mathrm{~h}$

Treated after washing with distilled water at $300^{\circ} \mathrm{C}$. With EDS analysis of the particle a and the particle $b$.

時間ではハイドラルサイト，168時間では AS (H)-Iがわずかに 副生していることがわかった。図 6 にはこれら生成物の TEM 写 真を示した。2 洔間の水熱処理で長さ $100 \mathrm{~nm}$ 程度, 幅 $5 \mathrm{~nm}$ 程

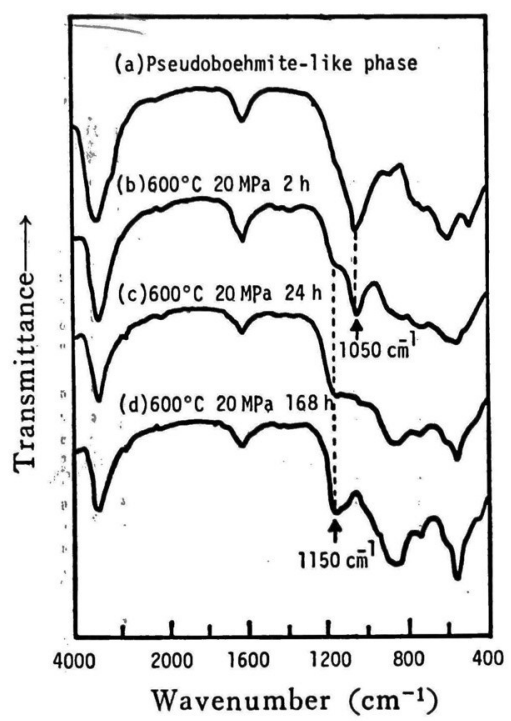

Fig. 9 IR absorption spectra of

(a) Pseudoboehmite-like phase, obtained by the direct hydrothermal treatment of mixed alkoxide*, at $300^{\circ} \mathrm{C}$ under $50 \mathrm{MPa}$

(b) (d) Products prepared by the hydrothermal treatment of mixed alkoxide*, at $600^{\circ} \mathrm{C}$ under $20 \mathrm{MPa}$ for various hours

Treated after washing with distilled water at $300^{\circ} \mathrm{C}$.

* $\mathrm{Al}_{2} \mathrm{O}_{3}: \mathrm{SiO}_{2}=3: 2$, mole ratio

度のムライト針状晶が見られ，水熱処理時間が長くなるとともに 釗状晶の量および大きさが増大し 168 時間の処理では長さ $1 \mu \mathrm{m}$ 以上, 幅 $20 \mathrm{~nm}$ 程度の針状晶となった。しかし 24 時間および 72 時間の水熱処理生成物中には針状晶のほかに，微細な板状物など も見られた。

これらの水熱処理生成物の EDS 分析の結果, 24 時間の水熱処 理生成物（図 7) は $\mathrm{Al}_{2} \mathrm{O}_{3} / \mathrm{SiO}_{2}$ モル比の異なる種々の粒子の混 合物であり，一方 168 時間の水熱処理生成物（図 8 ） は $\mathrm{Al}_{2} \mathrm{O}_{3}$ / $\mathrm{SiO}_{2}$ モル比 $=3 / 2$ の均一な厶ライト針状晶となっていることが わかった。すなわち, 水熱処理の初期段階ではムライトを含め種 々の組成の混合物が生成するが，水熱処理時間が長くなるにとも ない均一な組成のムライト針状晶が成長していくことがわかっ た。

これらの生成物の赤外吸収スペクトル（図 9）では，2時間の 水熱処理物に擬ベーマイト類似相と同様の $1050 \mathrm{~cm}^{-1}$ での吸収が 認められたが，処理時間が長くなるにともない $1050 \mathrm{~cm}^{-1}$ の吸収 は減少し，代わって $1150 \mathrm{~cm}^{-1}$ の吸収が増大し 168 時間ではムラ イトの吸収スペクトルとなった。ムライトはX線回折法ではシリ マナイト $\left(\mathrm{Al}_{2} \mathrm{O}_{3} \cdot \mathrm{SiO}_{2}\right)$ との区別が困難であり, 赤外吸収法によ り区別し得るといわれている21)。図 10 に示したように, 168 時 間の水熱処理生成物は, $1400^{\circ} \mathrm{C} 1$ 時間の焼成で得たムライトと同 様の赤外吸収スペクトルを示しシリマナイトおよび他のアルミ， ケイ酸塩（カイアナイト，アンダルサイト）とは明確に区別する ことができる。

\section{4 水熱処理中間生成物}

$600^{\circ} \mathrm{C}, 2$ 時間の水熱処理では圧力が $30 \mathrm{MPa}$ 以上の場合, 八 


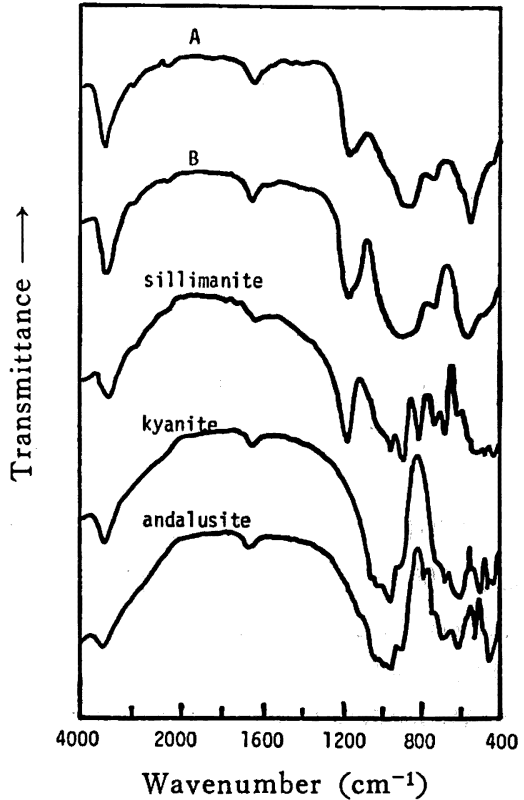

Fig. 10 IR absorption spectra of

(A) mullite obtained by hydrothermal treatment ( 600 ${ }^{\circ} \mathrm{C}, 20 \mathrm{MPa}, 168 \mathrm{~h}$ )

(B) mullite obtained by calcination $\left(1400^{\circ} \mathrm{C}, 1 \mathrm{~h}\right)$ from mixed alkoxide $\left(\mathrm{Al}_{2} \mathrm{O}_{3}: \mathrm{SiO}_{2}=3: 2\right.$, mole ratio) and minerals in the $\mathrm{Al}_{2} \mathrm{O}_{3}-\mathrm{SiO}_{2}$ system (sllimanite, kyanite, andalusite)

イドラルサイトおよび AS (H)-Iがムライトに優先して生成し た。また $600^{\circ} \mathrm{C}, 20 \mathrm{MPa}$ での水熱処理もムライト以外の副生成 物として 72 時間ではハイドラルサイト，168 時間では AS (H)IIが認められた。しかし TEM および EDS 分析の結果では，水 熱処理時間が 168 時間と長くなるにともない, 組成の均一な $\left(\mathrm{Al}_{2}\right.$ $\mathrm{O}_{3} / \mathrm{SiO}_{2}$ モル比＝3/2）ムライト針状晶となることがわかった。

一方, 圧力を $10,20,30,40,50,100 \mathrm{MPa}$ と変え $600^{\circ} \mathrm{C}$ で 2 時間水熱処理した生成物のX線回折図形（図 4) からわかるよ らに，圧力の上昇とともにハイドラルサイトおよび AS(H)-II の生成量が増大した。とくに AS (H)-II は 50〜100 MPa におい ていちじるしく結晶成長した。さらに 168 時間 (7 日間) 水熱処 理した場合（図 11）2 時間の処理にくらべムライトの生成量は

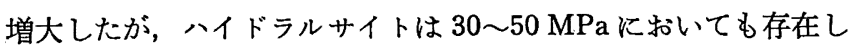
なかった。すなわち $600^{\circ} \mathrm{C}, 30 \sim 50 \mathrm{MPa}, 2$ 時間の水熱処理で生 成したハイドラルサイトは安定相ではなく，168 時間後には消隇 した。しかし，AS (H)-IIは 168 時間後も依然として存在してお。 り，しかも20 MPaにおいても生成が認められた（2 時間の処理 では $30 \mathrm{MPa}$ 以上で $\mathrm{AS}(\mathrm{H})$-II の生成を確認している)。 De Vijnck は共沈ゲルを $600^{\circ} \mathrm{C}, 400 \mathrm{~kg} / \mathrm{cm}^{2}$ (39.2 MPa), 7 日間 水熱処理してムライト単独相を得た旨報告しているが, 本研究の 結果では $600^{\circ} \mathrm{C}, 40 \mathrm{MPa}, 7$ 日間の水熱処理でムライトと AS (H)ーIIの混合相となった。

さらに長時間の变化を追究するため, $600^{\circ} \mathrm{C}$ において 20 およ び $30 \mathrm{MPa} て ゙ 336$ 時間（14 日間）水㓐処理した。600 $\mathrm{C}, 50 \mathrm{MPa}$ においては，7日間の処理ではいちじるしく成長していた AS (H)-II゙ほとんど消隇し，ムライトと少量の $\alpha$-アルミナなどの 生成が認められた（図 12）。したがって, AS(H)-II $600^{\circ} \mathrm{C}$,

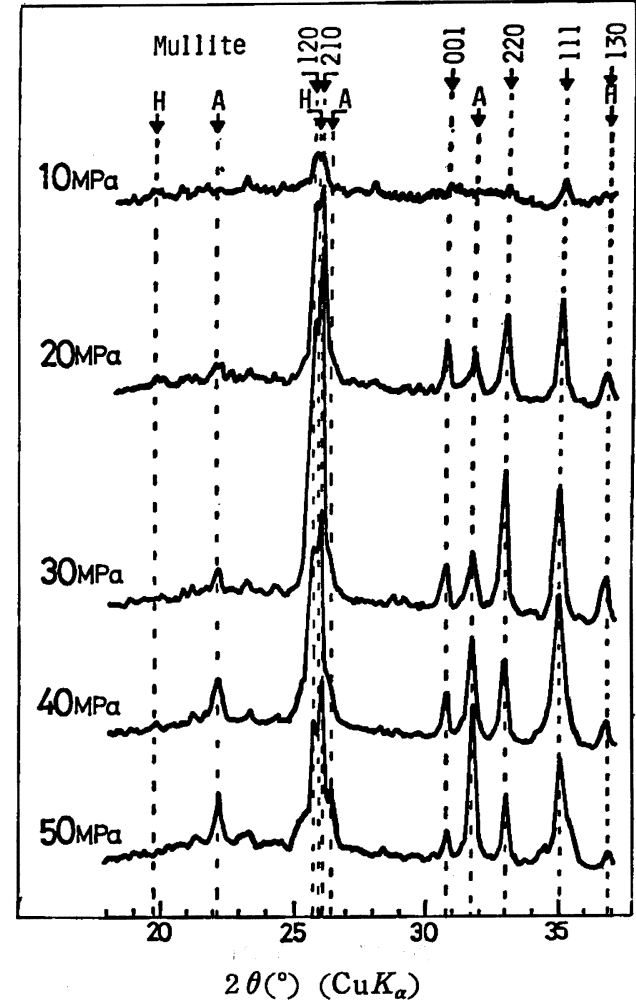

Fig. $11 \mathrm{X}$-ray powder diffraction patterns of products prepared by the hydrothermal treatment of mixed alkoxide $\left(\mathrm{Al}_{2} \mathrm{O}_{3}: \mathrm{SiO}_{2}=3: 2\right.$, mole ratio), under various pressures at $600^{\circ} \mathrm{C}$ for $168 \mathrm{~h}$

Treated after washing with distilled water at $300^{\circ} \mathrm{C}$. $\mathrm{H}:$ Hydralsite, A : AS (H)-II

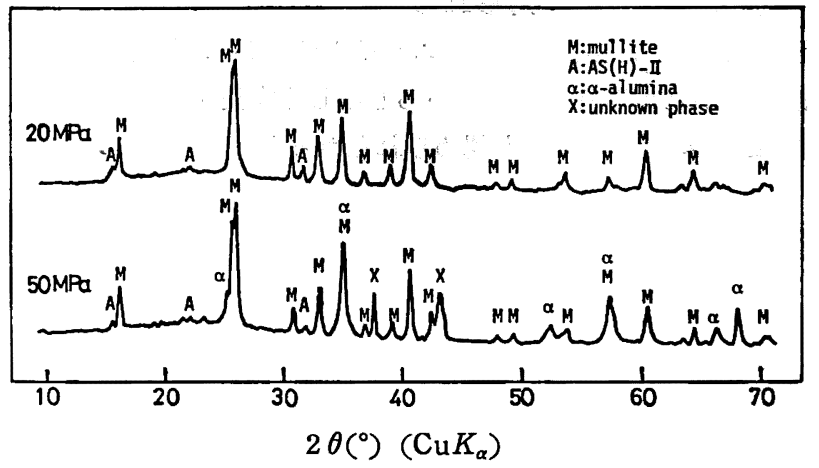

Fig. $12 \mathrm{X}$-ray powder diffraction patterns of products prepared by the hydrothermal treatment of mixed alkoxide $\left(\mathrm{Al}_{2} \mathrm{O}_{3}: \mathrm{SiO}_{2}=3: 2\right.$, mole ratio), at $600^{\circ} \mathrm{C}$ under 20 or $50 \mathrm{MPa}$ for $336 \mathrm{~h}$

Treated after washing with distilled water at $300^{\circ} \mathrm{C}$.

$20 \mathrm{MPa}$ 以上で生成する準安定相であり， $50 \mathrm{MPa}$ 以下の圧力下 では，やがて分解する性質のるのと考えられる。また AS $(\mathrm{H})$-II の EDS 分析の結果ではその組成は $5 \mathrm{Al}_{2} \mathrm{O}_{3} \cdot 2 \mathrm{SiO}_{2} \cdot n \mathrm{H}_{2} \mathrm{O}$ に近 く, ムライト $\left(3 \mathrm{Al}_{2} \mathrm{O}_{3} \cdot 2 \mathrm{SiO}_{2}\right)$ より $\mathrm{Al}_{2} \mathrm{O}_{3}$ に富んでいた のため AS(H)-II の分解によりムライトのほかに $\alpha$-アルミナが 析出するものと考兄られる。

因 13 には $600^{\circ} \mathrm{C}, 50 \mathrm{MPa}, 168$ 時間および 336 時間の水熱処 理生成物の SEM 写真を示した。前者にはいちじるしく結晶成長 


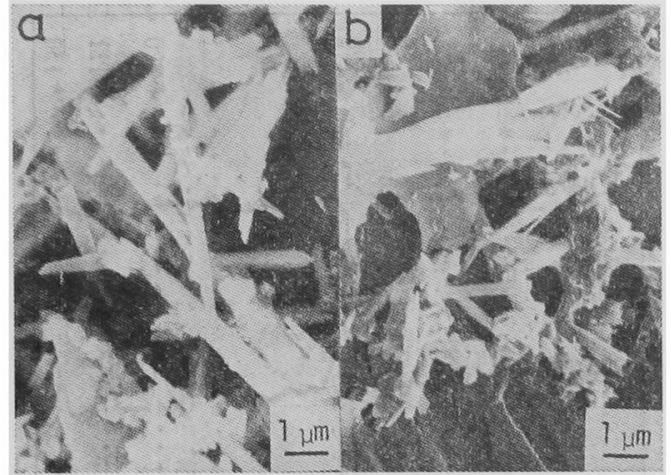

Fig. 13 SEM photographs of the products prepared by the hydrothermal treatment of mixed alkoxide $\left(\mathrm{Al}_{2} \mathrm{O}_{3}: \mathrm{SiO}_{2}=3: 2\right.$, mole ratio), at $600^{\circ} \mathrm{C}$ under $50 \mathrm{MPa}$ for (a) $168 \mathrm{~h}$ or (b) $336 \mathrm{~h}$

Treated after washing with distilled water at $300^{\circ} \mathrm{C}$.

(a) : AS (H)-II +Mullite, (b ): Mullite+ $\alpha$-Alumina

した AS (H)ーII゙見られた。後者にはこの AS (H)-IIが分解し て生成したムライト針状晶が見られたが，その大きさは不ぞろい であった。

このような結果から, $600^{\circ} \mathrm{C}$ で $30 \mathrm{MPa}$ 以上の高圧力で水熱処 理した場合, 水熱処理初期段階でハイドラルサイト $\left(2 \mathrm{Al}_{2} \mathrm{O}_{3} \cdot 2\right.$ $\left.\mathrm{SiO}_{2} \cdot \mathrm{H}_{2} \mathrm{O}\right)$ および AS (H)-II $\left(5 \mathrm{Al}_{2} \mathrm{O}_{3} \cdot 2 \mathrm{SiO}_{2} \cdot n \mathrm{H}_{2} \mathrm{O}\right)$ がム イト $\left(3 \mathrm{Al}_{2} \mathrm{O}_{3} \cdot 2 \mathrm{SiO}_{2}\right)$ に優先して生成し, やがて分解してムラ イトに変化するが, このとき, 同時に非晶質シリカあるいは $\alpha-$ アルミ゙などを析出するため, 均一組成のムライトが得難いるの と考えられる。このような理由からも水熱処理で均一組成の結晶

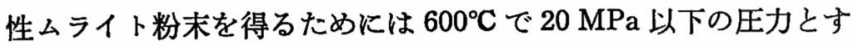
ることが好ましいと考克られる。600 $\mathrm{C}, 20 \mathrm{MPa} 336$ 時間水熱 処理した生成物（図 12）は, ムライトのほかに AS (H)-IIの生 成がわずかに見られるもののいちじるしく成長することはなく， また $\alpha$ ーアルミナの析出も認められなかった。

\section{4 結論}

$\mathrm{Al}_{2} \mathrm{O}_{3}: \mathrm{SiO}_{2}$ モル比 $=3: 2$ の混合アルコキシド溶液を $300^{\circ} \mathrm{C}$, $50 \mathrm{MPa}$ で 30 分間水熱処理後水洗し, $600^{\circ} \mathrm{C}, 10 \sim 100 \mathrm{MPa}$ で ふたたび水熱処理した結果，つぎのことがわかった。

（1）圧力 $20 \mathrm{MPa}$ 以上では 2 時間の水熱处理によってもムラ イトの生成が認められた。

（2）圧力 $30 \mathrm{MPa}$ 以上では, ハイドラルサイト, AS (H)-II などの水和物がムライトに優先して生成した。これらの水和物は 168〜336 時間の水熱処理で分解しムライトに変化するが，不均 一な組成になった。

（3） $600^{\circ} \mathrm{C}, 20 \mathrm{MPa}$ の条件で 2 168 時間水熱処理したとこ ろ, 2 時間で長さ $100 \mathrm{~nm}$, 幅 $5 \mathrm{~nm}$ の針状ムライトが生成し, 処理時間が長くなるのにともなって針状結晶が成長し, 168 時間 では長さ $1 \mu \mathrm{m}$ 以上, 幅 $20 \mathrm{~nm}$ となった。また EDS 分析の結果, 初期の生成物は $\mathrm{Al}_{2} \mathrm{O}_{3} / \mathrm{SiO}_{2}$ 比率の異なる粒子の混合物であった が, 168 時間後には $\mathrm{Al}_{2} \mathrm{O}_{3} / \mathrm{SiO}_{2}$ モル比 $=3 / 2$ の均一組成の針状 ムライト粒子となった。

（4） $600^{\circ} \mathrm{C}, 20 \mathrm{MPa}, 168$ 時間の水熱処理物は赤外吸収スペ クトルからも, ムライトであると同定できた。

加熱焼成でムライトを得るためには $1200^{\circ} \mathrm{C}$ 以上の焼成が必要 であるのに対し，水熱処理では $600^{\circ} \mathrm{C}$ といら低温でムライトが生 成する。しかも圧力を $20 \mathrm{MPa}$ 以下に制御することにより均一組 成でかつ形状の整った（針状晶の）ムライト粉末を得ることがで きる。しかし，そのためには 7 日以上の長期の水熱処理が必要で あった。したがって, 今後はこのような組成, 形状の整ったムラ イト粉末を短時間の水熱処理で得るための工夫が必要と考えられ る。

実験の遂行にあたり TEM など分析機器の使用にさいして御便 宜をいたたいた日本電子株式会社に感謝する。

(1983 年 4 月, Am. Ceram. Soc. 年会; 1983 年 5 月, 案業協 会年会(一部) 発表) 


\title{
Special Articles on \\ Chemistry of Fine Particles and Applications
}

\section{Synthesis of Crystalline Mullite Fine Powders at Low Temperature by Hydrothermal Treatment of Mixed Alkoxide}

\author{
Matsuo Suzuri*, Shun-ichi Hiraishi, Masahiro Yoshimura \\ and Shigeyuki Sōmrya \\ Research Laboratory of Engineering Materials and Department of Materials \\ Science, Tokyo Institute of Technology ; Nagatsuta, \\ Midori-ku, Yokohama-shi 227 Japan
}

\begin{abstract}
Hydrothermal conditions for the synthesis of mullite powders from mixed alkoxide containing $\mathrm{Al}_{2} \mathrm{O}_{3}: \mathrm{SiO}_{2}=3: 2$ (mole ratio) were investigated at $300 \sim 600^{\circ} \mathrm{C}$ under $10 \sim 100 \mathrm{MPa}$ for $2 \sim 168 \mathrm{~h}$. Above $20 \mathrm{MPa}$, fine crystalline mullite powders were obtained at $600^{\circ} \mathrm{C}$ within $2 \mathrm{~h}$. To produce homogeneous mullite powders, the hydrothermal treatments below $30 \mathrm{MPa}$ at $600^{\circ} \mathrm{C}$ were preferable, because hydralsite $\left(2 \mathrm{Al}_{2} \mathrm{O}_{3} \cdot 2 \mathrm{SiO}_{2} \cdot \mathrm{H}_{2} \mathrm{O}\right)$ and $\mathrm{AS}(\mathrm{H})-\mathrm{II}\left(5 \mathrm{Al}_{2} \mathrm{O}_{3} \cdot\right.$ $2 \mathrm{SiO}_{2} \cdot n \mathrm{H}_{2} \mathrm{O}$ ) were produced prior to mullite above $30 \mathrm{MPa}$ at $600^{\circ} \mathrm{C}$. In the produce prepared at $600^{\circ} \mathrm{C}$ under $20 \mathrm{MPa}$ for $2 \mathrm{~h}$, accicular particles of $100 \mathrm{~nm}$ in length and $20 \mathrm{~nm}$ in width were observed under the transmission electron microscope(TEM). The particles grew up to more than $1 \mu \mathrm{m}$ in length and $20 \mathrm{~nm}$ in width at $600^{\circ} \mathrm{C}$ under $20 \mathrm{MPa}$ for $168 \mathrm{~h}$. The energy dispersive spectrometry(EDS) proved that the prepared particles had the constant $\mathrm{Al}_{2} \mathrm{O}_{3} / \mathrm{SiO}_{2}$ mole ratio $(=3 / 2)$. The synthesized particles was revealed to be mullite by IR absoption method.
\end{abstract}

